\title{
Introduction
}

This text and translation of the month of July is the seventh volume of our projected twelve-volume text and English translation of the Armenian liturgical book known to Armenians as the Yaysmawurk: To the Orthodox it is called the Synaxarion or sometimes Menologion, and to westerners, especially Roman Catholics, it is generally known as the Martyrology. In our first volume, that of January, one can find a brief, introductory discussion of the history and primary versions of the Yaysmawurk and its historical place in the worship of the Armenian Church. ${ }^{1}$

\section{A Note on the Text and Translation}

As previously mentioned in the above referenced discussion, Bayan's edition of the Yaysmawurk', which we have been using as the text for our translation, is actually a compilation of two different versions. And there are instances where the witness from his second version is of sufficient interest to include in our text and translation. In this seventh volume, there are the following occasions where I have decided to include here the witness of the secondary version, whether to substitute for a shorter version in Bayan's base manuscript or to serve as an outright additional entry. It is to be remembered that our purpose here is not to compile a critical edition, but to provide for the faithful the fullest witness possible.

1. Mathews, On This Day: The Armenian Church Synaxarion-January, xvii-xx, although the history is far more complicated than that introductory discussion suggests. A summary account of its contents can be found in Zanetti, "Apophthegmes et histoires édifiantes dans le synaxaire arménien”. 
The first occasion occurs among the entries for July 9, where there is found both a short and a longer version of the entry celebrating the prophet Isaiah. The first version, in Bayan's base manuscript, provides only a brief mention of the prophet; the later manuscript, which Bayan labels throughout as $\mathbf{B}$, has a longer and fuller version. It is this latter version that we have opted to include in our text and translation below.

The second occasion involves the celebration of the life of Mary Magdalene. In this case, Bayan includes a short memorial of this witness of Christ's resurrection on July 13. As this account is much shorter and adds nothing to the longer account that is to be found on July 22, the date on which her feast is generally celebrated in the Christian world, this short account has been tacitly omitted entirely, and that of July 22 included here.

Among the entries for July 18, Bayan includes two separate versions of the martyrdom of Saint Marina. In this case, the version from his B manuscript is longer and fuller. I have therefore used this version, omitting that found in his base manuscript, and indicating in the notes a few significant variants between the two versions. The order too is now reversed. Rather than Marina first then Macrina as in Bayan's base manuscript, the order in our translation below is now first Macrina then Marina, following Bayan's B manuscript.

Bayan includes a rather long account of the lives and martyrdoms of the Russian brothers best known as Boris and Gleb, among the saints celebrated on July 24. This text is found in his base manuscript but, as long as this text is, it is nonetheless still shorter than the account already found for their celebration on May 5. And this shorter text follows nearly verbatim the corresponding text in the longer version found in the May entry, so it has been entirely omitted here.

Lastly, on July 11, Bayan adds in a footnote rather than in the text, a very long addition to the entry for the Birth of John the Baptist, just before the last sentence of the entry as found in his base manuscript. While it is almost certainly a gloss from a later scribe, I felt it was sufficiently interesting to be included in our translation. However, I have marked it as an addition and inserted it after the main entry, 
with the numbering $4 \mathrm{a}, 4 \mathrm{~b}, 4 \mathrm{c}$, etc., rather than providing it with continuous numerotation following from the main text.

As with the previous volumes, we have attempted in our English translation to reflect the Armenian text literally and accurately, but with a view to making the narrative clear and as close to native English as possible.

\section{Further Acknowledgments}

My deepest thanks are again due to many of the same people I have thanked in previous volumes. Here I mention specifically only my dear friend and colleague Anoushavan Srpazan Tanielian who yet again, despite a schedule that would cripple most of us mere mortals, still managed to find the time to read carefully through my entire text and translation and saved me from numerous errors and infelicities. To him and the many others who have helped in so many various ways I continue to ask for the guidance and protection of all the saints. Any and all errors and omissions that remain are to be laid at my feet alone. 
